\title{
Education system institutions and educational inequalities in Uruguay
}

\author{
Juan A. Bogliaccini and Federico Rodríguez
}

ABSTRACT

This article shows how certain aspects at the secondary level of Uruguay's public school system produce inequalities in student achievement. The 2006 edition of the Programme for International Student Assessment (PISA) (OECD, 2006a) points to three key aspects of the institutions that regulate secondary education that play a part in reproducing inequalities of origin, hindering the equalizing role that guides the education system. First, the teacher assignment mechanism has the dual effect of sending a revolving door of young and inexperienced teachers to schools in unfavourable sociocultural contexts as well as concentrating teachers with more experience in schools in favourable contexts. Second, the geography-based system for assigning students to schools reproduces the residential segregation process. Lastly, the centralized system for supplying educational and technological materials is inadequate to the needs of the schools.

KEYWORDS

JEL CLASSIFICATION

AUTHORS
Education, secondary education, scholastic achievement, quality in education, evaluation, teaching corps, schools, instructional materials, Uruguay

I24, I28, D31

Juan A. Bogliaccini is assistant professor in the Social and Political Science Department at the Universidad Católica del Uruguay. juan.bogliaccini@ucu.edu.uy

Federico Rodríguez is the director of the Studies, Research and Indicators Unit of the National Institute of Education Assessment, Uruguay. federico.rodriguez@correo.ucu.edu.uy 


\section{I}

\section{Introduction}

Uruguay has one of the highest indices of human development in Latin America and the region's lowest inequality rate. ${ }^{1}$ However, in the second half of the 20th century, it entered a period of economic stagnation that led to a slow but steady deterioration of sociocultural conditions and higher rates of poverty and inequality. The capacity of the welfare State to respond to the new structure of social risks eroded (Filgueira and others, 2005). Secondary education is one of the public policy sectors that has proven least adept at responding to the new structure of risks, in part due to the political standoff that the sector has been experiencing for the past three decades. In effect, the representation of various corporate interests at the management levels, combined with an identity crisis as to the social purpose of secondary education, are the main battlegrounds.

This paper maintains that the causes of inequalities in education should be analysed at multiple levels. This is not a problem that can be explained solely by an analysis at the individual level (household) or at the system level. The individual level has been studied more closely in Uruguay beginning with the pioneering study by Rama (1993), and studies on the effect that a student's home environment has on educational achievement are more prolific in the national literature. The purpose of this paper is to help understand the institutional roots of educational inequality.

\footnotetext{
1 With a Gini coefficient of 39.5, Uruguay has the lowest level of inequality in the region. For a full classification of global inequality levels, see World Bank, 2014.
}

The premise of this study is that Uruguay's public education system, which educates $83 \%$ of all secondary school students in the country, has not succeeded in adapting its main organizational components in line with the country's changing risk structure, which has exacerbated inequalities in educational achievement in two ways: through the exclusion of students from the system and through the segmentation of schools in terms of quality. With respect to discrepancies in quality, there are three main causes: the stability of teachers in schools; the type of relationship between teaching staff and central administration; and the mechanism used to assign students to schools.

The disconnect between the new social risks and the institutions regulating the education system has meant that a good part of the country's educational indicators have stalled. This is more problematic at the secondary level, where the evidence indicates that the country has not managed to improve either completion rates for the basic cycle of secondary education among young people aged 15 to 20 years or advancement rates to the second cycle of secondary education (see figure 1).

This paper is organized as follows. Following the Introduction, section II explains the three mechanisms underpinning Uruguay's education system that are failing to prevent socioeconomic inequalities from becoming educational inequalities. Section III presents the model prepared for the analysis of data and describes the variables included in it. Lastly, section IV presents the findings, and section $\mathrm{V}$ discusses the conclusions. 
FIGURE 1

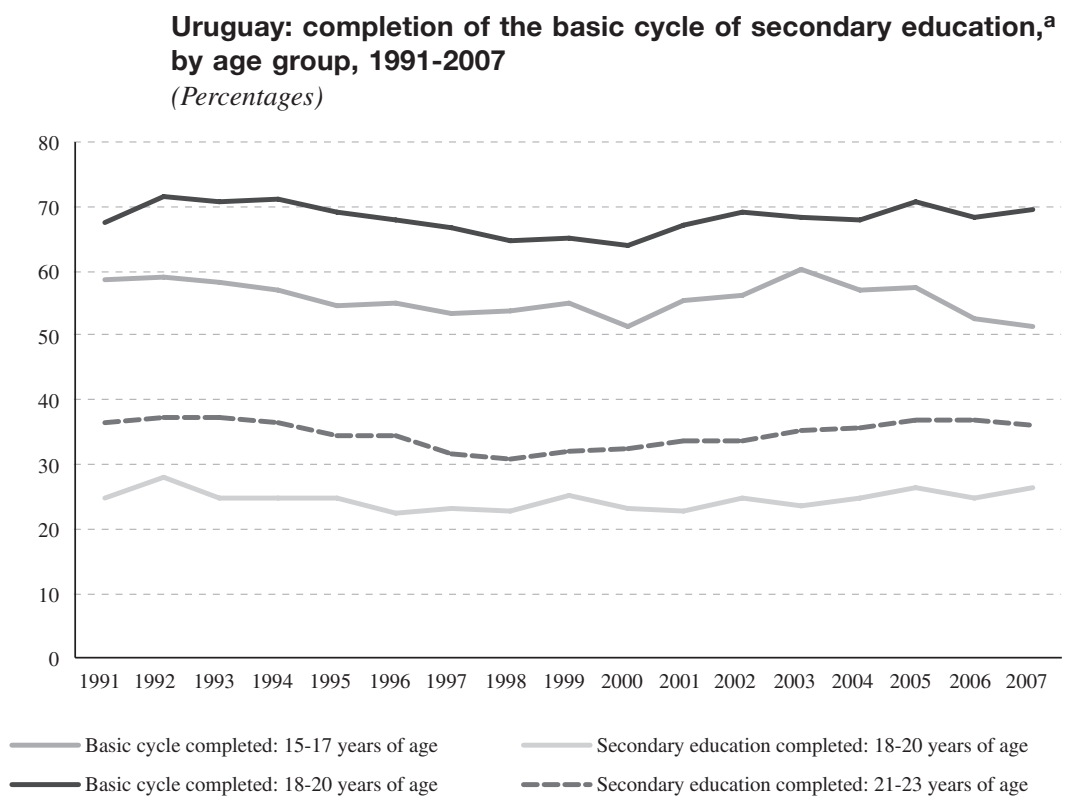

Source: Prepared by the authors, on the basis of data from the Central Administrative Council of the National Public Education Administration.

a 1 st to 3 rd year of secondary education.

\section{II}

\section{Regulation and inequality: hypothesis on causal links}

\section{Inequality and education: a difficult relationship}

What role does education play in social equity? The working idea inherited from the old paradigm is that education is a factor in social integration and the main socializing agent. With the publication of the Coleman Report (Coleman, 1966), the notion that schools have very little to offer when it comes to building social equity took hold, and other levels of analysis of educational achievement began to emerge, such as the family, the neighborhood and the school itself. Regarding the specific role that teaching staff and the education system play in student achievement, Hanushek and Luque (2001) show the disproportionate contribution that the school makes to educational attainment in low-income countries, compared with the contribution made by the family. In the case of Latin America, Cueto (2004) shows how the school has a larger influence on student achievement than indicated in the Coleman Report.
The World Conference on Education for All (Jomtien, Thailand, 1990) and the World Education Forum (Dakar, Senegal, 2000) set global targets in three key areas: coverage, quality and equity in education. In the years since, efforts have been redoubled to measure educational outcomes and processes, in order to more effectively identify the policies to be followed and evaluate the role of the various aforementioned factors in educational attainment.

The prevailing approaches to the study of social inequalities focused on education as a vehicle for reducing inequality. These schools of thought — such as feminist theory (Abbott, Tyler and Wallace, 1990; Stromquist, 1990), the effective schools approach (Edmonds, 1986; Fernández, 1999; Hanushek, Link and Woessmann, 2012) and the school composition and peer effects theory (Wilkinson and others, 2002; Sacerdote, 2001; Graham, 2008; De Giorgi, Pellizzari and Redaelli, 2010)_- were emerging and incorporating specific viewpoints that 
contributed to a better understanding of the inequalities present in society and how the educational environment either reflected them or offered a way to counter them. Of particular importance for this study were the findings reported by Hanushek and Woessmann (2010) on the relationship between educational performance and the type and quality of work obtained in the labour market. These authors noted the strength of this relationship across countries and regions, which underscores the policy importance of the question guiding this study.

Other works emphasize the importance of equality of opportunities (Roemer, 2005; Perera, Llambí and Messina, 2009; Méndez and Zerpa, 2009). Under this approach, which speaks more directly to the relationship between the regulations governing the education system and educational inequalities, giving individuals equal "opportunities of use" in line with their capacities is paramount. Thus, to minimize differences at the outset, the education system should level the playing field by ensuring that similarly talented individuals making the same degree of effort are able to achieve the same level of results, regardless of their family or social environment. According to this approach, institutional factors (educational conditions) are the key to more equitable outcomes (DiMaggio, 1982; Vélez, Schiefelbein and Valenzuela, 1994).

\section{The case of Uruguay: regulation and inequality}

Uruguay's education system is centrally run and regulated by the State, basically through the system of inspections and the standardized curriculum. ${ }^{2}$ In the period 1995-1999, the Sanguinetti administration oversaw the most sweeping reform of the education system in 70 years, underpinned by strategies to ensure equity in resources (with a compensatory emphasis) and results with centralized models that combined targeting and universality in the allocation of resources.

From the start of this reform to the Vázquez presidency (2005-2009), there were a number of structural tensions that went unresolved between the existing and emerging models in the education system. The debate, which was driven by political and ideological differences, sparked ongoing battles between the educational authorities and the teachers' unions, especially at the secondary level.

2 The main formal channel of communication between schools and the central administration takes the form of the inspector. The purpose of this position, which is competitively filled, is to evaluate teachers and principals, as well as to ensure the correct functioning of school facilities.
During the Vázquez administration, several of the changes introduced as part of the reform were reversed and others either slowed or stalled, and the most important educational innovations were run from outside the system, such as the CeIBAL Plan, which provides a personal computer to every student in the public schools (Martínez, Alonso and Díaz, 2009).

There are three aspects concerning the way in which the education system is currently run that are key to understanding the system's failure to maintain high levels of coverage and prevent socioeconomic inequalities among the students from becoming educational inequalities. First, the mechanism for assigning teachers to schools has the dual effect of sending a revolving door of young and inexperienced teachers to schools with unfavourable and highly unfavourable sociocultural conditions and concentrating teachers with more experience in favourable schools. Second, the system by which students are assigned to schools based on geography reproduces the social segregation process. Lastly, the centralized system for supplying educational and technological materials is inadequate to the needs of the schools, leading to a parallel system in which materials are provided based on the ability of the students' parents to meet those needs.

\section{(a) Teacher distribution by school}

The mechanism for assigning teachers and principals in the public school system stands in sharp contrast to its centralized model of administration. School selection rules give teachers the autonomy to select their preferred school, as well as to change schools at their discretion, within the framework of a hierarchical structure that gives seniority to the teachers who have worked the longest in the system. The hierarchically-based mechanism works as follows. Every year, the vacancies are announced. Once all open positions have been posted, a selection process is carried out in each department in the country. If a teacher wishes, he or she may register in up to two departments for the selection process. The current rules establish a complex mechanism governed by what is known as "order of precedence by grade in descending order."3 Basically, this means that full teachers make their selection before interns and substitutes; teachers at higher professional grades choose before those at lower grades; and within each grade, teachers with more points choose before those with fewer points. The teachers choose their schools by order of precedence, but

\footnotetext{
${ }^{3}$ See the Statutes on Teaching Personnel, particularly Articles 13 and 14. This same mechanism is set out in the rules for deconcentrated councils.
} 
there is a complementary mechanism that allows them to subsequently resign their chosen position and select, on an interim basis, a better position that was left vacant by another teacher. These vacancies occur from time to time by teachers who are taking leave or transferring to jobs with the National Public Education Administration (ANEP) or another public agency.

Accordingly, the final distribution of teachers in the schools depends on the individual decisions made by each teacher under these conditions. Neither the authorities, nor the principals, nor the parents have any say in the matter. ${ }^{4}$ The only constraints on teachers as they make their selections are the selections of other teachers, or more precisely, the selections of teachers better positioned in the "order of precedence."

This system favours teachers over students, inasmuch as it makes it impossible to incorporate into the system any type of strategic incentive or criteria in the distribution of teachers in schools. The most striking consequences are the segmentation of teachers by experience and chronic staffing instability in schools in more unfavourable areas. This, in turn, generates inequalities in two ways. First, teachers with more experience tend to be assigned to schools that are characterized by being located in more favourable neighborhoods and offering both cycles of secondary education (1st to 3rd years and 4th to 6th years, respectively). Second, the high turnover in schools located in less favourable areas diminishes their ability to coordinate, especially when it comes to following up with students who have significant learning challenges (Reimers, 2000; García Huidobro, 2003; Bogliaccini, 2003 and 2007). This leads to higher repeat and dropout rates (ANEP, 1999 and 2002; Filgueira, Fuentes and Rodríguez, 2006). The problem is worse at the secondary level and is consistent with the international evidence on good results, since a teacher selects positions in various schools, such that the last to choose must teach classes in different schools at some distance apart, which undermines the quality of the teaching and hinders coordination, increasing teacher absences (ANEP, 2005 and 2008).

\section{(b) Geography-based assignment of students to schools}

Assigning students who live within a certain radius of a school to that school, i.e. based on geographical proximity, in a society with relatively high levels of inequality and, even more importantly, with high levels

4 The ANEP authorities can act indirectly to eliminate, move or create positions. of residential segregation by social class, creates a school segmentation problem (Kaztman, 1999 and 2001; Filgueira and Bogliaccini, 2004; Kaztman and Retamoso, 2006). In societies with high rates of inequality, there are two major sources of risk with respect to educational segregation: the geographic recruitment base and a segmented educational supply in terms of quality and costs. Educational segregation should be understood as the situation that arises when the educational experience of an individual, or a group of individuals within the society, tends to be essentially the same experience of other individuals of the same social background. This segregation works to the detriment not only of the civic development of individuals within society but also of learning and educational achievement (Kaztman, 2001; Kaztman and Filgueira, 2001; ANEP, 2002).

The geography-based assignment of students to schools impairs educational equity by weakening the "peer effect" within the system (García Huidobro, 2000; Reimers, 2000; ANEP, 2002). However, given the number of secondary schools and their geographic distribution, segmentation at this level tends to manifest in a different, even counterintuitive, way than at the primary level (which consists of six years). In the latter case, segmentation is created by the existence of schools in which the entire student body is poor, since each urban neighborhood in Uruguay has its own public school. Meanwhile, at the secondary level, because there are fewer schools, they tend not to be located in unfavourable neighborhoods.

This means that the burden of heterogeneity is not shared equally across social classes. On the contrary, students from better backgrounds do not contribute to a rising tide through the "peer effect," and schools located in more unfavourable neighborhoods tend to receive a more heterogeneous student body from a larger radius, given that they must accept disadvantaged students from neighborhoods that do not have any or enough schools. ${ }^{5}$

This process of segmentation by "skimming" (Filgueira and Bogliaccini, 2004) worsens the inequalities in the system and is comparable to the process of residential segregation due to the development of private neighborhoods by social sectors with more resources. Over the past 30 years, these gated communities have sprung up rapidly in the region, a trend that has also

\footnotetext{
5 Unlike in the primary education system, where there has been an explicit policy for the past 20 years to build schools in the most critical neighborhoods, the process of expanding schools at the secondary level has been much slower.
} 
been seen in Uruguay though at a slower pace (Álvarez, 2007). Studies examining the effect of the school on performance include works by Formichella (2011) in Argentina; Oreiro and Valenzuela (2012) in Uruguay, and Fernández and Del Valle (2013) in Costa Rica.

\section{(c) Provision of educational and}

technological materials

Schools lack own resources for school furnishings and supplies, with the exception of items provided by parent associations. Schools must put in requests with the central administration for the items they need, or otherwise solicit donations from parent associations and other occasional benefactors (Da Silveira and Queirolo, 1998; Filgueira and Martínez, 2001).

As a result, there are major differences between schools in terms of instructional materials and technology, with two determining factors at play: the ability of school staff to negotiate with the central administration, and the economic capacity of the students' parents. In an index of basic instructional materials and equipment that was constructed using data from the technical systems at ANEP (1999), 24\% of schools in very unfavourable areas were found to have unmet needs, compared with just $2 \%$ of schools in favourable areas.

In summary, this article identifies three important factors in the institutional regulation of the school system that make it hard to correct performance inequalities: decentralized, teacher-driven decisions determining the distribution of teachers among schools, geographybased criteria for assigning students to schools and a nationally centralized system for supplying educational and technological resources.

\section{III}

\section{Variables and hypotheses}

In order to test the three suggested hypotheses, a logit model is proposed using 2006 data from the Programme for International Student Assessment (PISA) on 15-yearolds enrolled in the basic cycle of secondary school. Table 2 summarizes the variables that were used in the model, as well as the suggested hypotheses.

PISA is an international tool that assesses educational performance based on a representative sample of 15-yearold secondary school students in each participating country. The assessment is conducted every three years, with each round focusing in depth on one cognitive area (science, reading or mathematics). In addition to the assessment, PISA administers three questionnaires to be completed by the students, their families and the school principals. In 2006, Uruguay also participated in the international option to assess a sample of students in the second year of the basic cycle of secondary school, regardless of age. A comparison of the findings from 2003 and 2006 points up some important changes: (i) coverage of 15 -year-olds grew from $75 \%$ to $80 \%$; (ii) the percentage of students who were behind grew, especially in the first year of secondary school; (iii) the participation of vocational schools grew by four percentage points, and (iv) the percentage of students attending schools in very unfavourable areas doubled. In short, "between 2003 and 2006, the trend in Uruguay was mixed: it maintained its performance in mathematics but slipped in reading" (ANEP, 2007, p. 67).

The dependent variable is "scientific literacy," a binary variable built using the PISA scale of proficiency in science. ${ }^{6}$ The PISA survey groups test scores by levels that indicate the proficiency that the student is demonstrated to possess. Students at level 6 have achieved the highest level of difficulty, and those at level 0 are unable to complete the most basic tasks (see table 1). ${ }^{7}$ Students at levels 0 and 1 have not attained scientific literacy. According to the PISA technical report, "at level 2, students have adequate scientific knowledge to provide possible explanations in familiar contexts or draw conclusions based on simple investigations. They are capable of direct reasoning and making literal interpretations of the results of scientific inquiry or technological problem solving" (OECD, 2006b, p. 294). As a point of reference, in $2006,80.8 \%$ of students who completed the PISA test in the OECD countries placed at level 2 or higher.

\footnotetext{
6 The emphasis of the PISA assessment rotates between reading, mathematics and science. In 2006, the focus was on science. The same analysis could be repeated with either of the other two areas by consulting the database from other years $(2003,2009$ or 2012).

7 For more methodological information on how this variable is constructed, see OECD (2009, p. 134).
} 
The dependent variable was selected for three reasons. First, it can be interpreted in substantive terms. As established in the conceptual framework for the PISA test, the skills that define the threshold of proficiency in science - as in reading and mathematics - are the minimum required to be able to reasonably participate in the knowledge society, advanced studies and the labour market.

TABLE 1

Proficiency scale in science

\begin{tabular}{ccc}
\hline Levels & $\begin{array}{c}\text { Porcentage of } \\
\text { students }\end{array}$ & Scientific literacy \\
\hline 0 & 15.3 & Below the line \\
1 & 25.1 & $(40.4 \%)$ \\
2 & 32.1 & \\
3 & 18.5 & Above the line \\
4 & 7.4 & $(59.6 \%)$ \\
5 & 1.5 & \\
6 & 0.1 & \\
\hline
\end{tabular}

Source: Prepared by the authors, on the basis of data from Organization for Economic Cooperation and Development (OECD), PISA 2006 Technical Report, Paris, OECD Publishing, 2006.

Secondly, in the case of Uruguay, it has been shown that when controlling for social and family background, it is virtually guaranteed that students who have not developed these competencies by 15 years of age will not finish secondary school and thus will not advance to higher education (Bucheli and Casacuberta, 2000; Kaztman and Retamoso, 2007; Fernández, 2009; Fernández and others, 2010). Moreover, their job prospects will be nearly entirely limited to performing manual labour in relatively low-paying jobs without protections (Fernández and others, 2010). This, in turn, has serious implications in terms of the development models to which the country can aspire based on the degree of specialization of the available human capital.

The third reason has to do with the problem of equity. The PISA test consists of a set of scalable activities reflecting a wide range of skills that can be hierarchically ordered from the most basic to the most complex, which are ultimately expressed in a value continuum scale. Intuitively, a system that produces less inequality could be thought of as one in which the range of student outcomes is narrower, which can easily be determined using classic indicators such as variance, coefficient of variation, percentile spread, or measures such as the Gini coefficient. Although these measures are statistically potent, another reasonable way to think about the problem is in terms of the capacity of the education system to guarantee that all students have access to a standard set of lessons determined as necessary for the entire population.

In terms of the former approach, there are some cases in which high rates of equity can be normatively unacceptable, e.g. a system in which all students are below the proficiency threshold. The latter approach, which is the approach supported by this article, is less concerned about the prospect of an academic elite scoring far above the national average, instead focusing on the notion of universal access to a core set of skills and knowledge that school systems should guarantee. These approaches are not contradictory but rather complementary, inasmuch as the international empirical evidence shows that systems with higher performance levels are the same systems that succeed in minimizing gaps between their students (OECD, 2008).

The variable included in the model to measure the effect on literacy of the first factor considered that regulates the system is the "proportion of certified teachers at the school," measured as the percentage of teachers with a teaching certificate out of the total number of teachers at the school (OECD, 2006b, p. 308). Given that all public schools in the country must either have a fully certified teaching corps or distribute the number of certified teachers equally across schools, this variable helps test the hypothesis that the system in place for assigning teachers to schools has a negative effect on educational equality.

Hypothesis 1: the teacher assignment mechanism means that less desirable schools must fill positions with uncertified teachers, teachers in their final year of training, or teachers in their first year following training.

The second factor considered is "heterogeneity of school," measured as the standard deviation from the mean socioeconomic level of the student body.

Hypothesis 2: given the geographical distribution of secondary schools, those that are more heterogeneous will have a higher proportion of students falling below the "literacy" level.

The third factor considered is asymmetry in the distribution of technological and teaching resources among schools, as a result of the national centralisation of the system for supplying and repairing those resources. To capture this factor, two variables are used. "Shortages of technological resources" is a simple additive index of the shortages reported by the school principal of the number of computers available for instruction, software for those computers and audiovisual materials. The second variable is "shortages of instructional materials," measured as a 
simple additive index of the shortages reported by the school principal of textbooks and library resources. ${ }^{8}$

Hypothesis 3: the greater the shortages of resources, in both cases, the smaller the percentage will be of students in the school who attain literacy levels.

Table 2 summarizes the descriptive statistics for the variables included in the analysis (table A.1 shows the statistics for each dependent variable group). The variables included as controls at the student level are as follows: "sex," "socioeconomic level of the student," and "age-grade delay status." Previous studies in Uruguay have shown that in terms of "gender," on average, girls perform better than boys (Perera, Llambí and Messina, 2009). ${ }^{9}$ Given that the dependent variable in this model is "literacy," it is assumed that on average the proportion of proficiency above the literacy threshold will be greater

\footnotetext{
8 The PISA database offers an index of quality of school educational resources (SCMATEDU) that is computed from seven items that measure the school principal's perceptions about the possible factors hindering instruction at the school. This study does not use the index on the understanding that it is important to make a conceptual distinction between shortages of technological resources and shortages of instructional materials.

9 In general, with respect to the countries participating in the PISA survey, girls obtain higher scores than boys in reading, but boys score better in science and mathematics. However, the 2006 PISA A test in Uruguay did not yield any significant differences, as illustrated by the results of the statistical model.
}

among female students, but indicators are not available to put forth a hypothesis on the statistical importance of this difference in averages.

In relation to the "socioeconomic level of the student," it is estimated - following the literature on the topic — that the literacy percentage will be higher among students with higher socioeconomic levels.

With respect to "age-grade delay of student," the hypothesis is that this variable correlates inversely with the literacy rate. In this case, it should be noted that the PISA test is administered to 15 -year-old students, so it is not possible to compare students who have repeated a grade against those who have not in the same level of secondary education (delayed students are enrolled in lower grades than the grade that corresponds to their age).

Also included are two school-level control variables: "socioeconomic context of the school" and "type of school," either public or private. ${ }^{10}$ In the first case, the classification established by ANEP in 2006 was used, whereby schools were grouped into five categories ranging from a "very favourable" environment to a "very unfavourable" environment (ANEP, 2007). This classification has been used to test the importance that the

${ }^{10}$ Schools are urban (there are virtually no schools in rural areas of
Uruguay), and vocational schools were excluded from the analysis.

TABLE 2

Characteristics of independent variables

\begin{tabular}{|c|c|c|c|c|c|c|c|}
\hline \multirow[b]{2}{*}{ Variable } & \multicolumn{2}{|r|}{ Operationalisation } & \multirow[b]{2}{*}{$\begin{array}{l}\text { Effect on } \\
\text { literacy }\end{array}$} & \multirow[b]{2}{*}{ Mean } & \multirow[b]{2}{*}{$\begin{array}{l}\text { Standard } \\
\text { deviation }\end{array}$} & \multirow[b]{2}{*}{$\begin{array}{l}\text { Minimum } \\
\text { value }\end{array}$} & \multirow[b]{2}{*}{$\begin{array}{l}\text { Maximum } \\
\text { value }\end{array}$} \\
\hline & $\begin{array}{c}\text { Level of } \\
\text { measure- } \\
\text { ment }\end{array}$ & Categories & & & & & \\
\hline Sex & $\begin{array}{l}\text { Dummy } \\
\text { variable }\end{array}$ & $0=$ female, $1=$ male & Negative & 0.47 & 0.50 & 0 & 1 \\
\hline Context of student & Interval & Continuum, positive & Positive & 0.54 & 0.17 & 0 & 1 \\
\hline Age-grade delay of student & Dummy & $1=$ delayed & Negative & 0.15 & 0.35 & 0 & 1 \\
\hline $\begin{array}{l}\text { Proportion of certified teachers } \\
\text { at the school }\end{array}$ & Interval & Continuum & Positive & 61.91 & 18.61 & 20 & 100 \\
\hline Heterogeneity of school & Interval & Continuum & Positive & 0.92 & 0.20 & 0.9 & 2.3 \\
\hline Context of school & $\begin{array}{l}\text { Ordinal } \\
\text { variable }\end{array}$ & $\begin{array}{l}1=\text { very unfavourable } \\
5=\text { very favourable }\end{array}$ & Positive & 3.00 & 1.23 & 1 & 5 \\
\hline Context of school & Ordinal & $\begin{array}{l}0=\text { no shortages } \\
6=\text { maximum shortages }\end{array}$ & Negative & 3.20 & 1.95 & 0 & 6 \\
\hline \multirow{2}{*}{$\begin{array}{l}\text { Shortages of textbooks and } \\
\text { library resources }\end{array}$} & \multirow[t]{2}{*}{ Ordinal } & $0=$ no shortages & Negative & 2.00 & 1.24 & 0 & 4 \\
\hline & & $4=$ maximum shortages & & & 0.41 & & \\
\hline Type of school & Nominal & $0=$ private, $1=$ public & Negative & 0.84 & 0.49 & 0 & 1 \\
\hline
\end{tabular}

Source: Prepared by the authors, on the basis of data from Organization for Economic Cooperation and Development (OECD), PISA 2006 Technical Report, Paris, OECD Publishing, 2006. 
school environment has on student achievement, and it is clear that students perform better in a better environment (ANEP, 2007). As in the case of the individual context, the hypothesis is that this variable correlates positively with the literacy rate at the school.

Lastly, regarding the "type of school" and based on the work of Oreiro and Valenzuela (2012), the hypothesis is that private schools will have a smaller proportion of literate students than will public schools. It is important to note that there are no private schools in the "very unfavourable" socioeconomic category and, conversely, no public schools in the "very favourable" category. Thus, the effect of "type of school" on literacy is determined by restricting the comparison to the "unfavourable," "average," and "favourable" categories, in which there are both public and private schools.

\section{IV}

\section{Analytical technique and results}

The model proposed for this analysis is a binomial logit model. The results are interpreted based on the analysis of the probability of change in the dependent variable (between $0=$ illiterate and $1=$ literate) given a change of one unit in the independent variable, with all other variables remaining constant at their mean values: $\operatorname{Pr}(Y=1 \mid x)$ (Gelman and Hill, 2007; Gujarati, 2004). The model includes robust standard errors to correct for heteroskedasticity. ${ }^{11}$ The number of observations in the model is 4,276, taken from the Uruguay data from the 2006 edition of the PISA test. The gross participation rate in the test was $98.2 \%$ of the schools in the sample (PISA

\footnotetext{
11 The tests for ruling out multicollinearity (variance inflation factor) and homoskedasticity from the errors (Breusch-Pagan/Cook-Weisberg test) can be found in tables A.3 and A.4.
}

requires a school participation rate of $85 \%$ ). The rate of participation of students who completed both the test and the questionnaire was $83.16 \%$ of the effective sample (PISA requires a participation rate of at least $80 \%$ ). Table 3 presents the results of the model.

\section{Analysis of variables measured at the school level}

The model required four iterations to converge. A first analysis conducted at the centre of the data, the point at which the slope of the logistic curve is most pronounced, revealed the maximum magnitude of the effect of each independent variable on literacy. Among the schoollevel variables, the most important as concerns aspects of educational inequality related to how the school

TABLE 3

Logit effect of selected variables on illiteracy

\begin{tabular}{|c|c|c|c|c|c|}
\hline $\begin{array}{l}\text { Iteration 1: pseudolikelihood } \log = \\
\text { Iteration 4: pseudolikelihood } \log =\end{array}$ & $\begin{array}{ll}-2 & 878.3 \\
-2 & 250.6\end{array}$ & & & & \\
\hline & $\beta$ & $\beta / 4$ & $\sigma^{2}$ Robust & $\mathrm{Z}$ & Significance \\
\hline Sex & -0.048 & -0.012 & 0.090 & -0.53 & \\
\hline Context of student & 2.579 & 0.645 & 0.327 & 7.89 & $* * *$ \\
\hline Age-grade delay of student & -2.155 & -0.539 & 0.156 & -13.82 & $* * *$ \\
\hline Proportion of certified teachers at the school & 0.009 & 0.002 & 0.003 & 3.49 & $* * *$ \\
\hline Heterogeneity of school & -1.168 & -0.292 & 0.297 & -3.93 & $* * *$ \\
\hline Context of school & 0.459 & 0.115 & 0.059 & 7.82 & $* * *$ \\
\hline Shortages of technological resources & -0.069 & -0.017 & 0.036 & -1.89 & $*$ \\
\hline Shortages of textbooks and library resources & 0.061 & 0.015 & 0.048 & 1.27 & \\
\hline Type of school & 0.514 & 0.129 & 0.181 & 2.84 & $* *$ \\
\hline Intercept & -1.524 & -0.381 & 0.427 & -3.56 & $* * *$ \\
\hline
\end{tabular}

$\mathrm{N}=4276$; Wald $\operatorname{chi} 2(9)=640 ; \mathrm{LR}=1255 ; \mathrm{AIC}=4521$

Code: $* \mathrm{p}(\mathrm{Z})<0.05 ; * *<0.1 ; * * *<0.001$ (a tail)

Source: Prepared by the authors. 
system is run - the proportion of certified teachers at the school, the homogeneity of the school, context of the school, shortages of technological resources and type of school— are statistically significant.

The proportion of certified teachers at the school is statistically significant in explaining illiteracy. An increase of $10 \%$ in that proportion at the centre of the data, with other variables remaining constant at their averages, causes the likelihood of obtaining literacy results to rise by $2 \%$.

This finding supports the hypothesis put forth about the negative effect of the rules for filling teaching positions in the public sector, in which teacher preference is the only functionally strategic criterion. Individual teachers are limited only by the strategies of their colleagues exercising precedence in the selection process. This mechanism operates at the highest level of decentralisation (with the various levels identified as the central administration of the public school system, individuals schools and individual teachers), which does not allow for corrective measures in the system to improve equity in the distribution of resources among schools.

The effect is small but significant, which is to be expected given that the variable used as a proxy captures the difference in certification rates (and presumably teacher experience) but not the difference in the effect of teacher turnover. ${ }^{12}$ At any rate, the analysis of the model yields sufficient evidence to state definitively that this problem is a probable and important cause of educational inequality.

Heterogeneity at the school is also statistically significant and correlates negatively with the likelihood of rising out of the ranks of illiteracy. The less socioeconomically diverse the student body, the greater the likelihood will be that students will score above the literacy line. At the centre of the data, school heterogeneity in Uruguay is one (1) standard deviation from the mean of the context of the school. In this case, a onestep increase in school heterogeneity (from 0 to 1 ) leads to a $29 \%$ decrease in the likelihood of emerging from illiteracy.

These findings support the hypothesis that the mechanism for assigning students to schools based on geography has a regressive effect on the likelihood that a student will emerge from illiteracy. In a context of medium to high levels of residential segregation, the geography-based system segments the student body, preventing a distribution of students that would favour a positive "peer effect."

12 PISA does not provide a better indicator, and the ANEP has not made systematic measurements of this phenomenon publicly available.
The variable included in the model to measure shortages of textbooks and library materials is not statistically significant as an explanation for literacy levels. However, the variable on shortage of technological resources is statistically significant. At the centre of the data, a one-step increase in terms of the shortage of technological resources causes a $1.7 \%$ decline in the likelihood that a student will test as literate. ${ }^{13}$

In short, the hypothesis on the negative effect on equality of centralised mechanisms for supplying educational materials is corroborated by the model presented in this paper only in the case of technological resources. This finding is extremely important for understanding the risks related to equity and integration of the individual in a society that is seeking to close the digital divide.

\section{Analysis of three typical scenarios}

To illustrate the effects of the variables introduced in the model, a series of scenarios are presented to examine, under a discrete set of conditions, the likelihood that a student will score above the threshold for scientific literacy (levels 2 to 6 ). For greater clarity with respect to the hypotheses guiding the study, the scenarios assume that student characteristics (average student in the system) remain constant while school characteristics vary, in order to observe changes in the likelihood that the average student will score above the literacy line, depending on whether he or she is enrolled in an average school, a school among the $25 \%$ with the worst conditions or a school among the $25 \%$ with the best conditions.

\section{(a) Scenario 1}

In 2006, the average individual in the sample is a female student from a middle socioeconomic background (category 3) who had no age-grade delays and was enrolled in an average school with the following characteristics: the school is public, the average student is also from a middle socioeconomic background, the heterogeneity of the school is also at the midpoint of the distribution (a standard deviation of 0.9 ), 62\% of teachers are certified, there are shortages in at least two of the three categories included in the index of technological shortages and there are inadequate materials in at least one of category of instructional materials.

13 The 2006 PISA assessment was administered before President Vázquez's government launched the CEIBAL Plan, which provides a personal computer to every student enrolled in a public school at the primary level. 
The likelihood that this student will obtain a score on the PISA test that places her above the literacy line is $74 \%$. In other words, 3 of every 4 hypothetical students will score above level 1 (see table 1). If the student has one year of age-grade delay, the likelihood that she scores as literate is just $25 \%$. This figure is extremely important because of all the countries around the world participating in the PISA test, Uruguay is one of four with the highest rates of age-grade delays among 15 -year-olds. ${ }^{14}$

\section{(b) Scenario 2}

The same female student is assumed to attend a school with conditions that place it among the best $25 \%$ of schools in the country. In this school, the average student is from a middle socioeconomic background (i.e. the peer effect remains constant in this comparison), there is less heterogeneity (a standard deviation of 0.72),

${ }^{14}$ Uruguay has very high dropout rates among 15 -year-olds and agegrade delays (14\% of 15 -year-olds who have remained in school). This is an inefficient solution to the problem created by the tension between coverage and quality that is always present in any school system.
$73 \%$ of teachers are certified and there are technological shortages in just two of the three categories and shortages of instructional materials in just one. The likelihood that this same student will score above the literacy threshold is now $82 \%$ (compared with $74 \%$ in scenario 1 ). If the student has one year of age-grade delay, the likelihood drops to $34 \%$.

\section{(c) Scenario 3}

Lastly, the same student is assumed to attend a school with conditions that place it among the worst $25 \%$ of schools in the country. In this school, the average student comes from an unfavourable sociocultural context, there is more heterogeneity (a standard deviation of 1.05 ), only $47 \%$ of teachers are certified and there are technological shortages in all three categories and shortages of instructional materials in both categories. The likelihood that this same student will score above the literacy threshold is just 58\% (compared with $74 \%$ in scenario 1 and $82 \%$ in scenario 2). If the student has one year of agegrade delay, the likelihood drops to a mere $14 \%$.

\section{V}

\section{Conclusions}

The analysis presented here demonstrates that the mechanisms for assigning teachers and students to schools and distributing instructional materials have an adverse effect, producing and reproducing educational inequalities. First, the mechanism for assigning teachers to schools leads to the segmentation in the distribution of teachers based on the sociocultural context of the respective schools, which reinforces inequalities of origin among the students. Second, the mechanism for assigning students to schools leads to homogeneity in the student body of schools with favourable conditions, and heterogeneity in the student body of schools with average, unfavourable and very unfavourable conditions. Lastly, the mechanism for the provision and maintenance of technological resources for educational use reinforces unequal access to these resources in favour of schools in more favourable contexts.

The effect that teacher assignment mechanisms have on the distribution of skills and capacities among schools and the ensuing inequalities in quality and equity raise the problem of how to stop operating according to the "logic of the market" that the mechanism imposes. This is a clear "principalagent problem" in which the interests of the system diverge dramatically from those of the student body, begging the question as to what end is being served by allowing teachers to choose their school with no possibility for the system to intervene.

Assigning students who live within a certain radius of a school to that school reproduces patterns of residential segregation within the school and, thus, educational segmentation. During the 1995 education reform, some projects intended to break this dynamic were discussed, including a school busing policy that would have made it possible to transport students between districts, a proposal that was ultimately rejected for budgetary and political reasons. The risk of failing to implement policies to break this pattern is that school segmentation will become further entrenched, as the public school system expands through the construction of new schools in very unfavourable neighborhoods, generating a problem not unlike the one currently seen 
at the primary school level: the creation of cultural homogeneity in poor neighborhoods.

Signs of problems related to the highly centralised structure of the national school system are beginning to be seen in various aspects of how the system is run. The digital divide will clearly be a critical challenge in terms of overcoming inequality of opportunities in the years ahead, and Uruguay's education system does not seem poised to tackle it. At the same time, the CEIBAL Plan has succeeded in reducing the technology gap by a wide margin in primary education and is on the path to accomplishing the same at the secondary level. However, the success of this solution should not be used to mask the root of the problem, which lies in the differential access that schools have to resources and the problem that this gap in access then creates by reinforcing inequalities at the origin. Nor should it go unrecognized that this plan was developed outside the national education system (and is run by an technology innovation agency), owing in part to internal conflicts and opposition to the policy, even in late 2010, by the teaching corps.

In conclusion, the institutional challenges that the national education system must face in order to overcome problems related to coverage, quality and equity will require actions at two levels. First, the objectives of the secondary education cycle should be reformulated, followed by the institutional mechanisms in the service of those objectives. At present, instruction at the secondary level is not exclusively geared towards providing access to a university education, but rather also towards preparing students to enter the job market and vocational programs at post-secondary technical schools. The second area of action, which is related to the first, is for the education system to tackle problems related to sectoral corporatism, in order to advance towards the institutional changes needed to put student education above the interests of non-student actors in the system.

Lastly, the study presented here has its own limitations, namely the fact that is analyses only one category of the institutional aspects that can affect equity in educational achievement. In Uruguay, factors such as national exams, accountability, school choice and performance incentives have not been incorporated. As a result, the potential effect of these factors cannot be assessed. In addition, there are limitations in terms of the information available in the PISA databases and how to use the data to measures the desired concepts. Hopefully, future studies will be able to successfully transcend these limitations.

ANNEX

TABLE A.1

Descriptive statistics of the variables included in the analysis, by dependent variable category

\begin{tabular}{|c|c|c|c|c|}
\hline \multirow{2}{*}{ Variable } & \multicolumn{2}{|r|}{ Illiterate } & \multicolumn{2}{|r|}{ Literate } \\
\hline & Mean & Standard deviation & Mean & Standard deviation \\
\hline Sex & 0.48 & 0.50 & 0.46 & 0.50 \\
\hline Context of student & 0.47 & 0.16 & 0.59 & 0.16 \\
\hline Age-grade delay of student & 0.33 & 0.47 & 0.03 & 0.17 \\
\hline Proportion of certified teachers at the school & 56.77 & 18.13 & 63.10 & 18.49 \\
\hline Heterogeneity of school & 0.96 & 0.18 & 0.89 & 0.21 \\
\hline Context of school & 2.00 & 1.00 & 3.02 & 1.19 \\
\hline Shortages of technological resources & 3.79 & 1.73 & 2.89 & 2.00 \\
\hline Shortages of textbooks and library resources & 2.24 & 1.15 & 1.77 & 1.26 \\
\hline Type of school & 0.92 & 0.27 & 0.71 & 0.46 \\
\hline
\end{tabular}

Source: Prepared by the authors, on the basis of data from Organization for Economic Cooperation and Development (OECD), PISA 2006 Technical Report, Paris, OECD Publishing, 2006. 
TABLE A.2

\section{Description of variables used in the analysis}

\begin{tabular}{|c|c|}
\hline Variable & Description \\
\hline Sex & Sex of the student. \\
\hline Context of student & Index of household economic, social and cultural status (IESCS). \\
\hline Age-grade delay of student & $\begin{array}{l}\text { This is defined as a delay of two or more years in the educational career of a student with } \\
\text { respect to his/her cohorts. }\end{array}$ \\
\hline Proportion of certified teachers at the school & $\begin{array}{l}\text { This variable is calculated by dividing the number of fully certified teachers by the total } \\
\text { number of teachers. }\end{array}$ \\
\hline Context of school & $\begin{array}{l}\text { This is established based on the IESCS average for the student body at the school. It is a } \\
\text { measure of the central trend. }\end{array}$ \\
\hline Heterogeneity of school & $\begin{array}{l}\text { This is established based on the "context of school" variable, but it measures the internal } \\
\text { heterogeneity of the respective school, regardless of its relative "context" position. It is a } \\
\text { measure of dispersal. }\end{array}$ \\
\hline Shortages of technological resources & $\begin{array}{l}\text { This is a simple additive index based on the school principal's opinion about the shortages or } \\
\text { inadequacy of computers available for instruction, the shortages or inadequacy of educationa } \\
\text { software for the computers and the shortages or inadequacy of audiovisual resources } \\
\text { for instruction. }\end{array}$ \\
\hline Shortages of textbooks and library resources & $\begin{array}{l}\text { This is a simple additive index based on the school principal's opinion about the shortages or } \\
\text { inadequacy of textbooks and library resources at the school. }\end{array}$ \\
\hline Type of school & $\begin{array}{l}\text { A value of } 1 \text { is assigned when the school is private, and a value of } 0 \text { is assigned when the } \\
\text { school is public. }\end{array}$ \\
\hline
\end{tabular}

Source: Prepared by the authors.

TABLE A.3

Variance inflation factor (VIF) for the model

\begin{tabular}{|c|c|c|}
\hline Variable & VIF & $1 / \mathrm{VIF}$ \\
\hline Sex & 2.58 & 0.387055 \\
\hline Context of student & 2.47 & 0.405523 \\
\hline Proportion of certified teachers at the school & 2.03 & 0.492614 \\
\hline Heterogeneity of school & 1.56 & 0.639929 \\
\hline Context of school & 1.24 & 0.804850 \\
\hline Shortages of technological resources & 1.17 & 0.851628 \\
\hline Shortages of textbooks and library resources & 1.06 & 0.941546 \\
\hline Type of school & 1.02 & 0.982756 \\
\hline Mean VIF & 1.71 & \\
\hline
\end{tabular}

Source: Prepared by the authors, on the basis of data from Organization for Economic Cooperation and Development (OECD), PISA 2006 Technical Report, Paris, OECD Publishing, 2006.

TABLE A. 4

\section{Breusch-Pagan/Cook-Weisberg test for heteroskedasticity}

Ho: Constant variance

Variables: Adjusted illiteracy values

$\chi^{2}(1)=9.27$

$\mathrm{P}>\chi^{2}=0.0023$

Source: Prepared by the authors, on the basis of data from Organization for Economic Cooperation and Development (oECD), PISA 2006 Technical Report, Paris, OECD Publishing, 2006. 


\section{Bibliography}

Abbott, W., P. Tyler and C. Wallace (1990), An Introduction to Sociology: Feminist Perspectives, New York, Routledge.

Álvarez, M.J. (2007), "Golden ghettos: gated communities and class residential segregation in Montevideo", Environment and Planning A, vol. 39, No. 1.

ANEP (National Public Education Administration) (2008), Censo Nacional Docente, Montevideo.

(2007), Uruguay en PISA 2006, Montevideo.

(2005), Uruguay en el Programa PISA. Boletín Informativo, No. 5, Montevideo [online] http://www.anep.edu.uy/anep/ phocadownload/pisa/pisa2003/Boletines/Boletin $\% 20$ informativo\%2005\%20-\%202003.pdf.

(2002), "La repetición en la escuela pública en cifras", Serie Estadística, No. 3, Montevideo.

(1999), Estudio de los factores institucionales y pedagógicos que inciden en los aprendizajes en escuelas primarias de contextos sociales desfavorecidos en el Uruguay, Montevideo.

Bogliaccini, J. (2007), "Primary education: changing mainstay of Uruguay", International Handbook of Urban Education, G. Noblit and D. Pink (eds.), Springer.

(2003), "La autonomía del director de escuela", Revista Umbral 2000, No. 11.

Bucheli, M. and C. Casacuberta (2000), "Asistencia escolar y participación en el mercado de trabajo de los adolescentes en Uruguay", El Trimestre Económico, vol. 67, No. 267, Fondo de Cultura Económica.

Coleman, J. (1966), Equality of Educational Opportunity, Washington, D.C., Department of Education.

Cueto, S. (2004), "Factores predictivos del rendimiento escolar, deserción e ingreso a educación secundaria en una muestra de estudiantes de zonas rurales del Perú".

Da Silveira, P. and R. Queirolo (1998), "Análisis organizacional: cómo funciona la educación pública en Uruguay", Estudios, No. 6, Montevideo, Centre for Studies into Economic and Social Reality.

De Giorgi, G., M. Pellizzari and S. Redaelli (2010), "Identification of social interactions through partially overlapping peer groups", American Economic Journal: Applied Economics, vol. 2, No. 2, Nashville, Tennessee, American Economic Association.

DiMaggio, P. (1982), "Cultural capital and school success: the impact of status culture participation on the grades of Us high school students", American Sociological Review, vol. 47, No. 2, American Sociological Association.

Edmonds, R. (1986), "Characteristics of effective schools", The School Achievement of Minority Children: New Perspectives, U. Neisser (ed.), Routledge.

Fernández, T. (2009), "La desafiliación en la educación media en Uruguay. Una aproximación con base en el panel de estudiantes evaluados por PISA 2003", Revista Iberoamericana sobre Calidad, Eficacia y Cambio en Educación (REICE), vol. 7, No. 4.

(1999), "Análisis organizacional en educación”, Documento de Trabajo, No. 46, Montevideo, Social Sciences Faculty of the University of the Republic.

Fernández, T. and others (2010), La desafiliación en la Educación Media y Superior de Uruguay. Conceptos, estudios y políticas, Montevideo, University of the Republic.

Fernández, A. and R. del Valle (2013), "Inequality in education in Costa Rica: the gap between students in public and private schools. An analysis of the results of the Programme for International Student Assessment (PISA)", CEPAL Review, No. 111 (LC/G.2597-P), Santiago.

Filgueira, F. and E. Martínez (2001), La reforma educativa en Uruguay: Desafios y tendencias, "Alcance y resultados de las reformas educativas en Argentina, Chile y Uruguay" project, Buenos Aires, Inter-American Development Bank (IDB).
Filgueira, F. and J.A. Bogliaccini (2004), "Las reformas educativas en Chile y Uruguay: descentralización orientada al mercado versus centralismo estatista", Descentralización y políticas sociales en América Latina, R. Gomà and J. Jordana (eds.), Barcelona, Barcelona Centre for International Affairs (CIDOB).

Filgueira, C., A. Fuentes and F. Rodríguez (2006), "Viejos instrumentos de la inequidad educativa: repetición en primaria y su impacto sobre la equidad en Uruguay", Educación y brechas de equidad en América Latina, S. Cueto (ed.), Santiago, Fondo de Investigaciones Educativas.

Filgueira, F. and others (2005), "Estructura de riesgo y arquitectura de protección social en el Uruguay actual: crónica de un divorcio anunciado", Prisma, No. 21.

Formichella, M.M. (2011), "Do private schools in Argentina perform better because they are private?", CEPAL Review, No. 107 (LC/G.2508-P), Santiago.

García Huidobro, J.E. (2003), "La buena escuela", La centralidad de la escuela en la política educativa chilena de los 90, J.E. García Huidobro and C. Sotomayor, Santiago.

(2000), "La deserción y el fracaso escolar", Educación, pobreza y deserción escolar, Santiago, United Nations Children's Fund (UNICEF).

Gelman, A. and J. Hill (2007), Data Analysis Using Regression and Multilevel/Hierarchical models, Cambridge, Cambridge University Press.

Graham, B.S. (2008), "Identifying social interactions through conditional variance restrictions", Econometrica, vol. 76, No. 3, New York, The Econometric Society.

Gujarati, D. (2004), Basic Econometrics, McGraw-Hill.

Hanushek, E. and L. Woessmann (2010), "The economics of international differences in educational achievement", CESifo Working Papers Series, No. 3037, Munich, cEsifo Group.

Hanushek, E., S. Link and L. Woessmann (2012), "Does school autonomy make sense everywhere? Panel estimates from PISA", NBER Working Paper, No. 17591, Cambridge, Massachusetts, National Bureau of Economic Research.

Hanushek, A. and J. Luque (2001), "Efficiency and equity in schools around the world", Economics of Education Review, vol. 22, No. 5, Amsterdam, Elsevier.

Kaztman, R. (2001), "Seduced and abandoned: the social isolation of the urban poor", CEPAL Review, No. 75 (LC/G.2150-P), Santiago. (1999), Activos y estructura de oportunidades: estudios sobre las raíces de la vulnerabilidad social en Uruguay (LC/MVD/R.180), Montevideo, Economic Commission for Latin America and the Caribbean (ECLAC)/United Nations Development Programme (UNDP).

Kaztman, R. and F. Filgueira (2001), Panorama de la infancia y la familia en Uruguay, Montevideo, Catholic University of Uruguay.

Kaztman, R. and A. Retamoso (2007), "Effects of urban segregation on education in Montevideo", CEPAL Review, No. 91 (LC/G.2333-P), Santiago.

(2006), Aprendiendo Juntos. Retos a la educación desde los procesos de segregación urbana, Montevideo, Catholic University of Uruguay.

Martínez, A.L. (coord.), S. Alonso and D. Díaz (2009), Monitoreo y evaluación de impacto social del Plan CEIBAL. Metodología y primeros resultados a nivel nacional, Montevideo [online] http://www.ceibal.org.uy.

Méndez, N. and M. Zerpa (2009), "Desigualdad en las capacidades educativas en Uruguay y Chile", document presented at the First Seminar on Economics of Education, Montevideo, Faculty of Economics and Administration, University of the Republic.

OECD (Organization for Economic Cooperation and Development) (2009), PISA Data Analysis Manual. Second Edition, Paris, OECD Publishing. 
(2008), Informe PISA 2006. Competencias científicas para el mundo del mañana, Santillana.

(2006a), "Database-PISA 2006" [online] http://pisa2006. acer.edu.au/.

(2006b), PISA 2006 Technical Report, Paris, OECD Publishing.

Oreiro, C. and J.P. Valenzuela (2012), "Determinants of educational performance in Uruguay, 2003-2006”, CEPAL Review, No. 107 (LC/G.2536-P), Santiago.

Perera, M., C. Llambí and P. Messina (2009), "Desigualdad de oportunidades y el rol del sistema educativo en los logros de los jóvenes uruguayos", Documento de Trabajo, No. 4, Montevideo, Centre for Economic Research.

Rama, G. (1993), ¿Qué aprenden y quiénes aprenden en las escuelas públicas de Uruguay?, Montevideo, ECLAC office in Montevideo.

Reimers, F. (2000), Unequal Schools, Unequal Chances, Cambridge, Massachusetts, Harvard University Press.

Roemer, J. (2005), "Equality of opportunity", The New Palgrave Dictionary of Economics. S.N. Durlauf and L.E. Blume (eds.), Palgrave Macmillan.
Sacerdote, B. (2001), "Peer effects with random assignment: results for Dartmouth roommates", Quarterly Journal of Economics, vol. 116, No. 2, Oxford, Oxford University Press.

Stromquist, N.P. (1990), "Gender inequality in education: accounting for women's subordination”, British Journal of Sociology of Education, vol. 11, No. 2, Taylor \& Francis.

Vélez, E., E. Schiefelbein and J. Valenzuela (1994), "Factores que afectan el rendimiento académico en la educación primaria", Revista Latinoamericana de Innovaciones Educativas, No. 17, Buenos Aires, Organization of Ibero-American States for Education, Science and Culture.

Wilkinson, I. and others (2002), "Discussion: modeling and maximizing peer effects in school", International Journal of Educational Research, vol. 37, No. 5 .

World Bank (2014), "Gini Index Ranking" [online] http://data. worldbank.org/. 